\title{
Clinical-epidemiological profile of patients with pressure injuries in the hospital context
}

\section{Perfil clínico-epidemiológico dos pacientes com lesão por pressão no contexto hospitalar}

\section{Perfil clínico-epidemiológico de pacientes con lesión por presión en el contexto hospitalario}

\author{
Lidiane Souza Lima1,*, Neylor Rodrigo Oliveira Aragão1, Gleyce Kelly de Brito Brasileiro Santos², \\ Eduesley Santana Santos 3 , Cátia Suely Palmeira ${ }^{4}$
}

ORCID IDs

Lima LS (D) https://orcid.org/0000-0002-3615-2159

Aragão NRO (D) https://orcid.org/0000-0002-5283-511X

Santos GKBB (iD https://orcid.org/0000-0003-4578-5799

Santos ES (D) https://orcid.org/0000-0001-8545-5677

Palmeira CS (D) https://orcid.org/0000-0001-6328-8118

\section{HOW TO CITE}

Lima LS; Aragão NRO; Santos GKBB; Santos ES; Palmeira CS. Clinical-epidemiological profile of patients with pressure injuries in the hospital context. ESTIMA, Braz. J. Enterostomal Ther., 2020, 18: e2720. https://doi.org/10.30886/estima.v18.917_IN

\begin{abstract}
Objective: describe the clinical-epidemiological profile of patients with pressure injuries admitted to a university hospital. Method: descriptive study with 122 patients with pressure injuries admitted to a university hospital between January 2018 and December 2019. Data were collected from patients' medical records and from the Serviço Assistencial de Cuidados com a Pele (Skin Care Assistance Service) database. Descriptive statistics were used for data analysis. Results: pressure injuries predominated among adults and the elderly, browns, who studied up to elementary school and had no partner. There was a similarity between the sexes. The patients had, mainly, infectious disease, one or more comorbidities, nutritional alteration, mixed incontinence and used nutritional therapy, but did not present dermatitis associated with incontinence and smoking history.Most patients were classified as high risk of pressure injury. The study totaled 237 lesions, most of which were acquired before admission, not classifiable, located in the sacrococcygeal region, treated topically with hydrogel with alginate and hydrocolloid, and not healed at the time of hospital discharge. Conclusion: the study described important aspects of the characterization of pressure injuries, as well as the people affected by this serious health problem, which can optimize prevention and treatment actions.
\end{abstract}

DESCRIPTORS: Stomatherapy; Pressure injury; Epidemiology; Hospitals.

\footnotetext{
1. Escola Bahiana de Medicina e Saúde Pública - Curso de Especialização em Enfermagem em Estomaterapia - Salvador (BA), Brazil. 2. Universidade Federal de Sergipe - Departamento de Enfermagem - Lagarto (SE), Brazil.

3. Universidade Federal de Sergipe - Departamento de Enfermagem da - Programa de Pós-Graduação em Enfermagem Aracaju (SE), Brazil.

4. Escola Bahiana de Medicina e Saúde Pública - Curso de Graduação em Enfermagem - Salvador (BA), Brazil.

*Correspondence author: lidi_lima88@hotmail.com

Received: Jul. 06, 2020 | Accepted: Oct. 08, 2020
} 


\section{RESUMO}

Objetivo: descrever o perfil clínico-epidemiológico dos pacientes com lesão por pressão internados em um hospital universitário. Método: estudo descritivo com 122 pacientes com lesão por pressão internados em um hospital universitário, entre janeiro de 2018 e dezembro de 2019. Os dados foram coletados nos prontuários dos pacientes e no banco de dados do Serviço Assistencial de Cuidados com a Pele. Utilizou-se estatística descritiva para análise dos dados. Resultados: as lesões por pressão predominaram entre adultos e idosos, pardos, que estudaram até o ensino fundamental e não possuíam companheiro. Houve semelhança entre os sexos. Os pacientes possuíam, principalmente, doença infecciosa, uma ou mais comorbidades, alteração nutricional, incontinência mista e utilizavam terapia nutricional, mas não apresentavam dermatite associada à incontinência e histórico de tabagismo. A maioria dos pacientes foi classificada como risco alto de lesão por pressão. O estudo totalizou 237 lesões, sendo a maior parte adquirida antes da internação, não classificável, localizada na região sacrococcígea, tratada topicamente com hidrogel com alginato e hidrocoloide, e não cicatrizada no momento da alta hospitalar. Conclusão: o estudo descreveu aspectos importantes da caracterização das lesões por pressão, assim como das pessoas acometidas por esse grave problema de saúde, o que pode otimizar as ações de prevenção e tratamento.

DESCRITORES: Estomaterapia; Lesão por pressão; Epidemiologia; Hospitais.

\section{RESUMEN}

Objetivo: Describir el perfil clínico-epidemiológico de los pacientes con lesiones por presión ingresados en un hospital universitario. Métodos: Estudio descriptivo con 122 pacientes con lesiones por presión ingresados en un Hospital Universitario, entre enero / 2018 y diciembre / 2019. Los datos se obtuvieron de los registros médicos de los pacientes y de la base de datos del Servicio de Asistencia para el Cuidado de la Piel. Se utilizó estadística descriptiva para el análisis de datos. Resultados: Predominaron las lesiones por presión entre adultos y ancianos, pardos, que cursaron estudios hasta la primaria y no tenían pareja. Hubo similitud entre los sexos. Los pacientes presentaban, principalmente, enfermedad infecciosa, una o más comorbilidades, alteración nutricional, incontinencia mixta y utilizaban terapia nutricional, pero no presentaban dermatitis asociada a incontinencia y antecedentes de tabaquismo. La mayoría de los pacientes se clasificaron como de alto riesgo de lesión por presión. El estudio totalizó 237 lesiones, la mayoría de ellas adquiridas antes del ingreso, no clasificables, ubicadas en la región sacrococcígea, tratadas tópicamente con hidrogel con alginato e hidrocoloide y no cicatrizadas al momento del alta hospitalaria. Conclusión: El estudio describió aspectos importantes de la caracterización de las lesiones por presión, así como de las personas afectadas por este grave problema de salud, que pueden optimizar las acciones de prevención y tratamiento.

DESCRIPTORES: Úlcera Varicosa; Epidemiología; Perfil de Salud; Estomaterapia.

\section{INTRODUCTION}

Pressure injuries (PI) are a frequent phenomenon in health institutions at all levels of care. In Brazil, in 2017, there were 13,834 cases of PI and 5 deaths, for this reason, notified by health institutions, corresponding to $18.37 \%$ of notifications of adverse events and $1.14 \%$ of deaths resulting from this type of event. However, the real extent of this problem is still unknown, since the Agência Nacional de Vigilância Sanitária (National Health Surveillance Agency) admits the occurrence of underreporting admite a ocorrência de subnotificações ${ }^{1}$.

The National Pressure Injury Advisory Panel (NPIAP), an internationally recognized organization for its commitment to the prevention and management of PI, defines them as localized damage to the skin and/or underlying soft tissues, usually on a bony prominence or related to the use of a medical device or other artifact. The lesion may appear on intact skin or as an open ulcer and occurs as a result of intense and/or prolonged pressure in combination with shear ${ }^{2}$.

In general, PI results from a complex combination of risk factors intrinsic and extrinsic to the patient. The deficit in mobility, activity and perfusion are the most frequent predictors in the development of these lesions, as well as the presence of an area of unbleachable hyperemia in the skin (PI stage 1). Other factors can also be mentioned: nutrition, general health, hematological changes, age, skin moisture, body temperature, immunity, use of vasoactive drugs, sedation and comorbidities (e.g. diabetis mellitus and vascular disease) $)^{3}$.

As a consequence of the PI, there is an increase in the length of hospital stay and the rate of morbidity and mortality, which results in a considerable increase in health care costs related to the human, material and physical resources of the health system ${ }^{4,5}$.

In Brazil, a study carried out in a palliative care unit in Minas Gerais calculated an annual cost of approximately $\mathrm{R} \$ 445,664.38$ for the treatment of PI and concluded that 
the prevalence of these injuries and the inappropriate use of materials are directly proportional to the care costs. ${ }^{5}$.

PI are classified in stages according to the layer of skin that has been affected. Stage 1 PI refers to a defined area of unbleachable hyperemia in the skin; in stage 2 PI there is exposure of the dermis; stage 3 PI reaches the subcutaneous tissue; stage 4 PI affects the deeper tissues, such as fascia, muscle, tendon, ligament, cartilage or bone; in the nonclassifiable stage, a necrosis layer covers the wound bed, and it is not possible to classify it; the deep tissue PI is an area of dark red, brown or purple discoloration, persistent and that does not whiten. PI can also occur in the mucous membrane and/or in association with a medical device ${ }^{2}$.

When assessing a patient's risk of developing PI, several known risk factors should be considered. To guide this assessment, there are specific and scientifically proven predictive instruments, such as the Braden Scale. The patient is classified as risk-free or with low, moderate or high risk, according to the score obtained in the subscales: sensory perception, humidity, activity, mobility, nutrition and friction/shear ${ }^{6}$.

Health care, when well managed, can result in a positive impact on the safety and quality of the service offered, on the quality of life and the level of satisfaction of professionals and customers. Therefore, this study is justified by adding knowledge about the population most affected by PI, as well as the characteristics of these injuries, in order to help health professionals plan health care based on scientific evidence and local reality, optimizing the allocation of physical, human and financial resources.

\section{OBJECTIVE}

To describe the clinical-epidemiological profile of patients with PI admitted to a university hospital.

\section{METHOD}

Descriptive, documentary study, carried out at Hospital Universitário de Sergipe, campus Aracaju, a teaching hospital, fully integrated with the Unified Health System (Sistema Único de Saúde) and a reference in medical and hospital assistance of medium and high complexity in the State. The hospital has an installed physical capacity of 111 hospital beds, 36 of which belong to the Medical Clinic, 36 to the Surgical Clinic, 11 to Pediatrics, 10 to the Intensive Care Unit and 18 to Oncology.

All patients admitted to the study site with PI or who developed it during hospitalization, from January 2018 to December 2019, comprised the study population, which was made up of 122 participants, so no sample was extracted.

The data were collected from February to March 2020, in the patients' medical records and in the database of the Skin Care Assistance Service (Serviço Assistencial de Cuidados com a Pele-SACP) in which the skin lesions of all patients being monitored are recorded, as well as the treatment instituted. It is noteworthy that due to the pandemic of Coronavirus Disease (COVID-19), in which social isolation was recommended, it was not possible to collect data on the clinical variables of all participants, since access to the patients' medical files became restricted.

For data collection, a specific instrument developed by the authors was used, consisting of sociodemographic and clinical variables, such as: age, sex, education, marital status, race, diagnosis at admission, inpatient unit, comorbidities (diabetes mellitus, arterial hypertension, heart failure, anemia or depression), nutritional alteration (obesity or malnutrition), use of nutritional therapy (enteral and/or parenteral), presence of incontinence, dermatitis associated with incontinence and smoking. The classifications of schooling and marital status used correspond to those adopted by the place of study for purposes of registering hospitalization.

The data collection instrument also presented the risk classification for developing PI, according to the Braden $\mathrm{Scale}^{6}$, and variables related to injuries: classification according to NPIAP (2019) -, anatomical location, origin, initial topical treatment and situation of the injury at the time of hospital discharge.

The collected data was stored in a database in Microsoft Office Excel and later exported to Statistical Package for Social Science (SPSS), version 20.0, to be processed and analyzed. Categorical variables were described by absolute and relative frequencies and the items of scale and sum of total results by measures of central tendency and dispersion (mean and deviation).

The research was authorized by the Teaching and Research Management of the place of study and approved by the Research Ethics Committee of the Universidade Federal de Sergipe according to CAAE no 09946119.40000.5546. 


\section{RESULTS}

In this research, there were 122 patients, with a mean age of $54 \pm 24$ years and a predominance of adults (43.3\%) and elderly (45.1\%). Men and women had an equal participation in the study (50.0\% each). Most participants studied up to elementary school (47.5\%), declared that they did not have a partner (59.0\%) and were of brown color (95.9\%) (Table 1)

Table 1. Sociodemographic aspects of the study population $(n=122)$. Aracaju (SE), Brasil - 2020.

\begin{tabular}{|c|c|}
\hline Age range & n (\%) \\
\hline Elderly (60 years and over) & $55(45.1)$ \\
\hline Adults (20 - 59 years) & $53(43.3)$ \\
\hline Adolescents (11 - 19 years) & $6(4.9)$ \\
\hline Schoolers (5 - 10 years) & $3(2.5)$ \\
\hline Infant (0 - 2 years) & $3(2.5)$ \\
\hline Preschoolers ( 2 - 4 years) & $2(1.6)$ \\
\hline Gender & $\mathrm{n}(\%)$ \\
\hline Male & $61(50.0)$ \\
\hline Female & $61(50.0)$ \\
\hline Education & n (\%) \\
\hline Elementary School & $58(47.5)$ \\
\hline None/lgnored & $34(27.8)$ \\
\hline High school & $27(22.1)$ \\
\hline Higher education & $3(2.4)$ \\
\hline Marital status & n (\%) \\
\hline Single/Widowed/Separated & $72(59.0)$ \\
\hline Married/Stable relationship & $38(31.1)$ \\
\hline Others & $12(9.9)$ \\
\hline Race & n (\%) \\
\hline Brown & $117(95.9)$ \\
\hline Black & $3(2.5)$ \\
\hline Without declaration & $2(1.6)$ \\
\hline
\end{tabular}

Infectious diseases were more frequent (35.2\%) among the causes of hospitalization of the research participants. As well as the medical clinic (54.1\%) and intensive care units (21.3\%) were those with the highest number of patients hospitalized with PI (Table 2).

Regarding the other clinical variables, most of the subjects had one or more comorbidities (68.9\%), had changes in nutritional status (56.6\%) and used nutritional therapy (45.9\%) (Table 2).

Most of the subjects surveyed had urinary, fecal and / or mixed incontinence (60.7\%). However, he did not have dermatitis associated with incontinence (51.6\%), as well as a smoking history (84.4\%) (Table 2).

Table 2. Clinical aspects of the study population. Aracaju (SE), Brasil - 2020.

\begin{tabular}{|c|c|}
\hline Inpatient unit $(n=122)$ & $\mathrm{n}(\%)$ \\
\hline Medical Clinic Unit & $66(54.1)$ \\
\hline Intensive care unit & $26(21.3)$ \\
\hline Oncology Unit & $12(9.8)$ \\
\hline Surgical Clinic Unit & $10(8.2)$ \\
\hline Pediatric Unit & $8(6.6)$ \\
\hline Diagnosis at admission $(n=122)$ & $\mathrm{n}(\%)$ \\
\hline Infectious disease & $43(35.2)$ \\
\hline Others(1) & $42(34.4)$ \\
\hline Lung Disease & $19(15.6)$ \\
\hline Gastrointestinal disease & $18(14.8)$ \\
\hline Comorbidities $(n=113)$ & $\mathrm{n}(\%)$ \\
\hline One or more comorbidities & 84 (68.9) \\
\hline No comorbidities & $29(23.8)$ \\
\hline Nutritional alteration $(n=118)$ & $\mathrm{n}(\%)$ \\
\hline Yes & $69(56.6)$ \\
\hline No & $49(40.2)$ \\
\hline Nutritional therapy $(n=96)$ & n (\%) \\
\hline Yes & $56(45.9)$ \\
\hline No & $40(32.8)$ \\
\hline Incontinence $(n=117)$ & n (\%) \\
\hline Mixed (urinary and fecal) & $66(54.1)$ \\
\hline Without incontinence & $43(35.2)$ \\
\hline Urinary & $5(4.1)$ \\
\hline Fecal & $3(2.5)$ \\
\hline $\begin{array}{l}\text { Dermatitis associated with } \\
\text { incontinence }(n=107)\end{array}$ & n (\%) \\
\hline No & $63(51.6)$ \\
\hline Yes & $44(36.1)$ \\
\hline Smoking $(n=113)$ & n (\%) \\
\hline No & $103(84.4)$ \\
\hline Yes & $10(8.2)$ \\
\hline
\end{tabular}

(1) It includes genitourinary, neuromotor, neoplastic, hematological, vascular, cardiac, metabolic, autoimmune, dermatological disease. 
Most of the research participants were classified as high risk (68.9\%) to develop PI, followed by moderate risk (18.0\%), according to the Braden Scale (Table 3).

The total PI presented by the 122 patients was 237 , an average of 1.9 injuries per patient and the majority of participants (63.1\%) had only one injury. Most of the injuries studied were acquired prior to admission to the study site (79.3\%) (Table 3).

Regarding the classification of the lesions, 25.3\% corresponded to the non-classifiable lesion, followed by the stage $2(22.4 \%)$ and deep tissue lesions (12.2\%). The predominant anatomical locations for the appearance of these injuries were the sacrococcygeal (36.3\%) and calcaneus (21.1\%) regions. Regarding treatment, alginate hydrogel (20.7\%) and hydrocolloid (19.8\%) were the most used initial topical treatments. Most injuries were not healed at the time of hospital discharge (46.5\%) (Table 3).

Table 3. Characterization of pressure injuries and the risk of developing them. Aracaju (SE), Brasil - 2020.

\begin{tabular}{|c|c|}
\hline PI risk ( $n=122)$ & n (\%) \\
\hline High Risk & $84(68,9)$ \\
\hline Moderate Risk & $22(18,0)$ \\
\hline Low Risk & $11(9,0)$ \\
\hline No Risk & $5(4,1)$ \\
\hline Origin $(n=237)$ & $\mathrm{n}(\%)$ \\
\hline Prior to hospitalization & $188(79,3)$ \\
\hline Acquired in the institution & $49(20,7)$ \\
\hline PI Classification ( $n=237$ ) & n (\%) \\
\hline Unclassifiable PI & $60(25,3)$ \\
\hline Stage 2 & $53(22,4)$ \\
\hline Deep Tissue & $29(12,2)$ \\
\hline Stage 3 & $27(11,4)$ \\
\hline Stage 4 & $27(11,4)$ \\
\hline Stage 1 & $20(8,4)$ \\
\hline PI Associated with Medical Device & $20(8,4)$ \\
\hline Pl in mucous membrane & $1(0,4)$ \\
\hline Anatomical location $(n=237)$ & $\mathrm{n}(\%)$ \\
\hline Sacrococcygeal & $86(36,3)$ \\
\hline Others(1) & $70(29,5)$ \\
\hline Calcaneal & $50(21,1)$ \\
\hline Ischia & $31(13,1)$ \\
\hline
\end{tabular}

continue...
Table 3. Continuation,..

\begin{tabular}{|c|c|}
\hline Initial topical treatment $(n=237)$ & n (\%) \\
\hline Others(2) & $65(27.4)$ \\
\hline Hydrogel with alginate & $49(20.7)$ \\
\hline Hydrocolloid & $47(19.8)$ \\
\hline Papain & $22(9.3)$ \\
\hline Hydrocellular foam for sacral region & $18(7.6)$ \\
\hline Collagenase & $14(5.9)$ \\
\hline Rayon gauze with EFA & $12(5.1)$ \\
\hline No topical treatment & $10(4.2)$ \\
\hline $\begin{array}{l}\text { Condition of } \mathrm{PI} \text { at hospital discharge } \\
\qquad(\mathrm{n}=237)\end{array}$ & n (\%) \\
\hline Unhealed WITH SACP guidance & $94(39,7)$ \\
\hline Does not apply (death) & $65(27,4)$ \\
\hline Healed & $62(26,2)$ \\
\hline Unhealed WITHOUT SACP guidance & $16(6,8)$ \\
\hline
\end{tabular}

$\mathrm{Pl}=$ Pressure injury; (1) Includes trochanters, back, elbows, occiput, shoulder blades, buttocks, ribs, malleoli, ear, nose, mouth, backbone;

(2) Includes polyurethane foam with and without silver, alginate plate with and without silver, silver sulfadiazine, gauze impregnated with Biguanide Polyhexamethylene (BPHM), EFA oil, barbatimon and BPHM gel.; EFA = Essential Fatty Acids; SACP = Serviço Assistencial de Cuidados com a Pele (Skin Care Assistance Service).

Regarding only the PI acquired at the study site, most were classified as stage $2(40.8 \%)$, followed by the non-classifiable (24.5\%), and the majority affected the sacrococcygeal region (55.1\%). The most used treatments were also hydrocolloid (36.7\%) and hydrogel with alginate (26.5\%). Only $18.4 \%$ of the injuries were not healed at the time of hospital discharge (Table 4).

Table 4. Characterization of pressure injuries acquired at the study site and condition of the injury at hospital discharge $(n=49)$. Aracaju (SE), Brasil - 2020.

$\begin{array}{cc}\text { PI Classification } & \mathrm{n}(\%) \\ \text { Stage } 2 & 20(40.8) \\ \text { Unclassifiable PI } & 12(24.5) \\ \text { St Associated with medical device } 1 & 6(12.2) \\ \text { Deep Tissue } & 5(10.2) \\ \text { Stage } 3 & 1(2.0) \\ \text { Pl in mucous membrane } & 1(2.0)\end{array}$

continue... 
Table 4. Continuation.

\begin{tabular}{|c|c|}
\hline Anatomical location & n (\%) \\
\hline Sacrococcygeal & $27(55.1)$ \\
\hline Others ${ }^{(1)}$ & $9(18.3)$ \\
\hline Calcaneal & $6(12.2)$ \\
\hline Trochanters & $5(10.2)$ \\
\hline Dorse & $2(4.1)$ \\
\hline Initial topical treatment & $\mathrm{n}(\%)$ \\
\hline Hydrocolloid & $18(36.7)$ \\
\hline Hydrogel with alginate & $13(26.5)$ \\
\hline Hydrocellular foam for sacral region & $7(14.3)$ \\
\hline Others $^{(2)}$ & $6(12.2)$ \\
\hline No topical treatment & $5(10.2)$ \\
\hline Condition of PI at hospital discharge & n (\%) \\
\hline Does not apply (death) & $22(44.9)$ \\
\hline Healed & $18(36.7)$ \\
\hline Unhealed WITH SACP guidance & $7(14.3)$ \\
\hline Unhealed WITHOUT SACP guidance & $2(4.1)$ \\
\hline
\end{tabular}

$\mathrm{PI}=$ Pressure injury; ${ }^{(1)}$ Includes elbows, occiput, shoulder blades, buttocks, ribs, malleoli, ear, nose, mouth, backbone; (2) Includes rayon gauze with EFA, collagenase, papain, polyurethane foam without silver and siliconized foam; SACP = Serviço Assistencial de Cuidados com a Pele (Skin Care Assistance Service).

\section{DISCUSSION}

In the present study, a greater number of injuries were identified in elderly people, which corroborates the literature ${ }^{3,7,8}$.This fact may be related to the physiological changes inherent to aging, such as decreased skin turgor and elasticity; presence of comorbidities, such as hypertension and stroke, more frequent in this age group; and also the use of medications, such as painkillers, antihypertensives and anticoagulants ${ }^{9,10}$.

In the elderly, the involvement of chronic noncommunicable diseases can not only affect the perceptual capacity, blood circulation, oxygenation, mobility, level of consciousness, levels of electrolytes and proteins, but also increase the probability of complications resulting from the long period of hospital stay, including risk of PI. Therefore, the importance of meeting the needs and maintaining the functional capacity of this population in order to prevent complications?.
In this study, there was no difference in the number of patients according to sex for the occurrence of PI. A study conducted with patients hospitalized for external causes shows a higher incidence of males ${ }^{7,9}$. However, research carried out in the Intensive Care Unit of a general hospital indicates a predominance of females ${ }^{11}$ or similar incidence between the sexes ${ }^{8}$, which demonstrates the absence of consensus on the topic.

Infectious diseases were the main diagnosis that justified the admission of research participants, followed by lung diseases. Among infectious diseases, infections specifically of the respiratory tract appear among the predominant pathologies in patients with $\mathrm{PI}^{5,7}$. It is known that in the face of dyspnea, patients become restricted to the bed and feel more comfortable with the head of the bed elevated above $30^{\circ}$. This reduces the ability to relieve pressure on bony prominences and increases the intensity and duration of pressure in the sacral region ${ }^{2,11}$.

The medical clinic and intensive care units had a higher frequency of PI, which corroborates other studies ${ }^{7,12}$.This finding may be associated with the clinical profile of patients seen at these locations, as they are more likely to experience debilitating conditions, advanced age, comorbidities, immobility, incontinence, in addition to the use of medications that interfere with the ability to maintain and recover skin tissue, impair mobility and sensory perception, such as sedatives and painkillers ${ }^{12}$.

Another important finding in this study was the high percentage of people hospitalized with comorbidities, such as diabetes mellitus, systemic arterial hypertension and heart failure, which reflects the complexity of the clinical conditions of the research participants. These diseases are considered important risk factors for PI, since the different pathophysiologies alter the skin's blood perfusion with the possibility of tissue ischemia ${ }^{3}$. In addition, your pharmacological therapies can also affect blood flow and make tissues more susceptible to pressure ${ }^{12}$.

Still concerning clinical conditions, it is worth mentioning that more than half of the participants in this study had nutritional changes at the time of admission. Nutritional deficit and dehydration play a role in the genesis and healing of PI, since they can cause loss of muscle mass, exposure of bony prominences, edema, reduced mobility and cutaneous blood flow, in addition to other pathophysiological changes that result in ischemic skin lesions. Adequate intake of calories, proteins, vitamins, 
minerals and liquids is essential for the repair and maintenance of tissue integrity ${ }^{13}$.

On the other hand, obesity not only contributes to immobility, greater exposure to moisture and difficulty in inspection and skin care, but also makes it difficult for the health team to change the position to relieve pressure in bone prominence sites. Although the literature points out that both malnourished and extremely obese patients are twice as likely to develop skin lesions as eutrophic people, it appears that overweight and mildly obese patients have some protective factor against the onset of $\mathrm{PI}^{14}$.

Thus, it is essential that health professionals are trained to assess the nutritional status, hydration and diet acceptance of assisted patients, given their importance in the development of PI, as well as acting early on strategies for the prevention and treatment of these injuries.

Although smoking represents an important risk factor for the appearance of PI due to changes in vascular response ${ }^{15}$, in this study the percentage of smokers was very small.

Urinary and/or fecal incontinence are also considered important risk factors for PI due to the excess moisture offered to the skin associated with the effects of proteolytic enzymes present in the faeces and the acidic $\mathrm{pH}$ of the urine. Both harm the skin and impair its integrity, which favors the appearance of maceration, physical and chemical irritation and dermatitis ${ }^{16}$.Thus, patients with mixed incontinence are more likely to develop PI, especially in the sacral region, when compared to those without incontinence or with isolated urinary or fecal incontinence ${ }^{17}$.

On the other hand, incontinent patients because they demand repeated cleaning of the genitalia and anal region must have the sacrococcygeal region and buttocks inspected frequently, which allows the early detection of the first signs of $\mathrm{PI}^{18}$. Because of these situations, special attention is required to hygiene care during hospital stay and orientation of the patient and family when at home.

Even with hygiene care, the appearance of incontinenceassociated dermatitis (IAD) is possible, which is an independent risk factor for PI, especially in the regions mentioned above and in the elderly population ${ }^{17,19}$. It should be noted that one of the challenges for nursing professionals is to recognize IAD, which in many situations is confused with PI in its early stages ${ }^{20}$.

Regarding the risk of PI, assessed according to the Braden Scale, it was observed that most patients were classified as having moderate or high risk, although patients without risk or with low risk also developed PI. It is observed that this scale has moderate predictive validity and could be improved if it considered the attributes of the study subjects, that is, other important risk factors for $\mathrm{PI}$, such as age, medication use, level of consciousness, comorbidities, among others ${ }^{21}$. However, the ease of application of the scale justifies its wide use ${ }^{22}$.

It is worth mentioning that the number of patients admitted with PI was higher than that of those who developed it after hospitalization in the researched place. Similar finding is observed in other studies 5 . It is believed that the advent of the Programa Nacional de Segurança do Paciente (National Patient Safety Program), in 2013, which provides for preventive actions for PI, was important in reducing the incidence rates of PI in health institutions.

When considering only injuries acquired at the study site, the predominance of stage $2 \mathrm{PI}$ is observed, which coincides with the literature ${ }^{7,8}$. This may mean that in a hospital there is greater surveillance of skin conditions, causing the first signs of PI to be detected early, leading to a lower frequency of more serious injuries. It is also necessary to consider the fact that at the place of study there are protocols for skin evaluation and prevention of PI, which helps professionals in decision making and, therefore, more effective care.

The aforementioned protocols are carried out by the SACP, which is responsible for planning actions and preparing institutional documents within the PI prevention and treatment program; carry out training and updating of assistance teams; request standardization and purchase of products and materials for the prevention and treatment of these injuries; and supervise assistance. A survey conducted in 2016 found a 69\% reduction in the incidence of PI after applying a prevention program, with potential cost savings of approximately US\$ 1 million ${ }^{22}$.

When assessing the anatomical location of the PI of the participants in this research, a higher frequency is observed in the sacrococcygeal region, coinciding with other studies ${ }^{3,7,8,11}$. This region is more frequently affected in the elderly and in patients with an additional diagnosis of urinary and/or fecal incontinence due to the fragility of the skin with aging and the action of moisture, urine acidity and proteolytic enzymes present in the feces, as previously discussed $^{2,16,17,19}$. 
The treatment of PI is based on the reduction or elimination of the pressure source and general care for the wound, that is, cleaning, control of humidity, temperature and microbial load and debridement of necrotic tissue ${ }^{23}$. For this, topical products are used that favor the ideal means for healing. Hydrocolloid and alginate hydrogel, the main coatings adopted in the researched location, are products capable of providing moisture retention, mechanical protection, isolation, barrier against bacteria and autolytic debridement ${ }^{24}$.

Although foams, collagen and growth factor are the most effective options for the treatment of PI, there is a lack of robust research that can consider the wide heterogeneity of the coverings, the dynamics of the healing process and the other factors that influence healing. Thus, it is not possible to safely determine which coverings are more likely to heal $\mathrm{PI}^{25}$. In this context, when selecting a coverage, the characteristics of the lesion and its anatomical location must be analyzed, in addition to the specific functions of each product, its availability and the cost-benefit ratio ${ }^{23}$.

It can be highlighted as limitations of the study: (1) difficulty in accessing the medical records of the research participants, which made it impossible to consider the totality of data related to clinical variables; (2) how the data were recorded in the SACP database, which did not allow the use of a cross-sectional approach; (3) unicentric study. Therefore, it is recommended to carry out multicenter studies on the subject.

Despite the limitations, the study allowed to know important aspects of PI, as well as the people who are affected by this serious health problem. Despite the findings reflecting a local reality, it is believed that they can guide the decision making of care teams and managers regarding the prevention and treatment of $\mathrm{PI}$, in addition to assisting in the prediction of human, physical, material and care costs in various scenarios in the health sector.

\section{CONCLUSION}

PI affected mainly adults and the elderly with infectious diseases, comorbidities, nutritional changes, some type of incontinence and were classified as having high risk of PI. The lesions, mostly, were located in the sacrococcygeal region, were in an unclassifiable stage, were treated with hydrogel with alginate and hydrocolloid and were not healed at the time of hospital discharge.

Because they are a multifactorial condition and can reach different body topographies, PIs should always be investigated, prevented and treated early and regularly during hospitalization. For this, it is essential to form a multidisciplinary work team, known generically as the Skin Commission, with a focus on defining the institutional standards and protocols for the prevention and treatment of $\mathrm{PI}$, as well as supporting the care teams in clinical practice.

\section{AUTHORS ‘CONTRIBUTION}

\section{Conceptualization: Lima LS, Aragão NRO and Santos} GKBB; Formal analysis: Santos ES and Palmeira CS; Investigation: Lima LS and Aragão NRO; Methodology: Lima LS, Aragão NRO, Santos GKBB, Santos ES and Palmeira CS; Writing - First version: Lima LS and Aragão NRO; Writing - Review \& Editing: Lima LS, Aragão NRO and Palmeira CS.

\section{REFERENCES}

1. Agência Nacional de Vigilância Sanitária (BR). Boletim segurança do paciente e qualidade em serviços de saúde n. 18: incidentes relacionados à assistência à saúde - 2017. [Cited 3 jan 2020], Portal ANVISA 2018. Available at: https://www20. anvisa.gov.br/segurancadopaciente/index.php/publicacoes/ item/boletim-seguranca-do-paciente-e-qualidade-emservicos-de-saude-n-18-avaliacao-dos-indicadoresnacionais-das-infeccoes-relacionadas-a-assistencia-a-saudeiras-e-resistencia-microbiana-do-ano-de-2017
2. European pressure ulcer advisory panel, National pressure injury advisory panel, Pan pacific pressure injury alliance. Prevention and treatment of pressure ulcers/ injuries: clinical practice guideline. $3^{\mathrm{a}}$ ed; [Cited 2020 feb 6]; 2019:408. Available at: https://www.biosanas.com.br/ uploads/outros/artigos_cientificos/127/956e02196892d71 40b9bb3cdf116d13b.pdf

3. Rocha SS, Falcone APM, Pontes EDS, Rocha SRS. Análise da presença de lesão por pressão em pacientes hospitalizados 
e as principais comorbidades associadas. Res Soc Dev 2020;9(4):e150943009. https://doi.org/10.33448/rsd-v9i4.3009

4. Qaseem A, Mir TP, Starkey M, Denberg TD. Risk assessment and prevention of pressure ulcers: a clinical practice guideline from the American College of Physicians. Ann Intern Med 2015 Mar;162(5):359-69. https://doi.org/10.7326/M14-1567

5. Costa AM, Matozinhos ACS, Trigueiro PS, Cunha RCG, Moreira LR. Custos do tratamento de úlceras por pressão em unidade de cuidados prolongados em uma instituição hospitalar de Minas Gerais. Enfermagem Revista 2015 jan/ abr; [Cited 2020 mar 6]; 18(1):58-74. Available at: http:// periodicos.pucminas.br/index.php/enfermagemrevista/ article/view/9378\#: : text=0\%20custo\%20 com\%20 material\%20para,recursos\%20dispon\%C3\%ADveis\%20 forem\%20usados\%20inadequadamente

6. Braden BJ, Maklebust J. Preventing pressure ulcers with the Braden scale: an update on this easy-to-use tool that assesses a patient's risk. Am J Nurs 2005 Jun;105(6):70-2. https://doi.org/10.1097/00000446-200506000-00031

7. Sanders LSC, Pinto FJM. Ocorrência de úlcera por pressão em pacientes internados em um hospital público de Fortaleza-CE. Rev Min Enferm 2012 abr/jun; [Cited 2020 apr 4]; 16(2):166-70. Available at: https://cdn.publisher.gn1.link/ reme.org.br/pdf/v16n2a03.pdf

8. Teixeira AKS, Nascimento TS, Sousa ITL, Sampaio LRL, Pinheiro ARM. Incidência de lesões por pressão em Unidade de Terapia Intensiva em hospital com acreditação. ESTIMA Braz J Enterostomal Ther 2017 jul/set;15(3):152-60. https:// doi.org/10.5327/Z1806-3144201700030006

9. Freitas MC, Medeiros ABF, Guedes MVC, Almeida PC, Galiza FT, Nogueira JM. Úlcera por pressão em idosos institucionalizados: análise da prevalência e fatores de risco. Rev Gaúcha Enferm 2011 mar;32(1):143-50. https://doi. org/10.1590/S1983-14472011000100019

10. Guimarães RVA. Prevalência e caracterização das lesões crônicas no município da região metropolitana de Belo Horizonte - MG [monografia]. Belo Horizonte (MG): Curso de Especialização em Estratégia do Cuidar em Enfermagem, Universidade Federal de Minas Gerais; 2019.

11. Silva DRA, Bezerra SMG, Costa JP, Luz MHBA, Lopes VCA, Nogueira LT. Pressure ulcer dressings in critical patients: a cost analysis. Rev esc enferm USP 2017;51:e03231. https:// doi.org/10.1590/s1980-220×2016014803231

12. Leites AWR, Almeida TQR, Arrué AM, Ribeiro GPR, Danski VRR, Reichembach MT. Pressure injury in adult patients hospitalized and served by a specialized skin service in the largest hospital in Paraná. Res Soc Dev 2020;9(9):e168996924. https://doi. org/10.33448/rsd-v9i9.6924

13. Kennerly S, Boss L, Yap TL, Batchelor-Murphy M, Horn SD, Barrett $R$ et al. Utility of braden scale nutrition subscale ratings as an indicator of dietary intake and weight outcomes among nursing home residents at risk for pressure ulcers. Healthcare. 2015;3(4):879-97. https://doi.org/10.3390/ healthcare3040879
14. Hyun S, Li X, Vermillion B, Newton C, Fall M, Kaewprag P et al. Body mass index and pressure ulcers: improved predictability of pressure ulcers in intensive care patients. Am J Crit Care 2014 Nov;23(6):494-501. https://doi. org/10.4037/ajcc2014535

15 Li C, DiPiro ND, Cao Y, Szlachcic Y, Krause J. The association between metabolic syndrome and pressure ulcers among individuals living with spinal cord injury. Spinal Cord 2016 Nov;54(11):967-72. https://doi.org/10.1038/sc.2016.53

16 Beeckman D. A decade of research on incontinenceassociated dermatitis (IAD): evidence, knowledge gaps and next steps. J Tissue Viability 2017 Feb;26(1):47-56. https:// doi.org/10.1016/j.jtv.2016.02.004

17 Gray M, Giuliano KK. Incontinence-Associated Dermatitis, characteristics and relationship to pressure injury: a multisite epidemiologic analysis. J Wound Ostomy Continence Nurs 2018 Jan;45(1):63-67. https://doi.org/10.1097/ WON.0000000000000390

18. Sousa Júnior BS, Mendonça AEO, Duarte FHS, Silva CC. Riscos para o desenvolvimento de úlceras por pressão em idosos utilizando as subescalas de Braden. Rev Enferm Atual In Derme 2016;77(15):37-43. https://doi.org/10.31011/reaid2016-v.77-n.15-art.372

19 Hödl M, Blanař V, Amir Y, Lohrmann C. Association between incontinence, incontinence-associated dermatitis and pressure injuries: a multisite study among hospitalised patients 65 years or older. Australas J Dermatol 2020 Feb;61(1):e144-e46. https://doi.org/10.1111/ajd.13163

20 Chianca TCM, Gonçales PC, Salgado PO, Machado BO, Amorim GL, Alcoforado CLGC. Dermatite associada à incontinência: estudo de coorte em pacientes críticos. Rev Gaúcha Enferm 2016;37(espe):e68075. https://doi. org/10.1590/1983-1447.2016.esp.68075

21 Park S-H, Choi Y-K, Kang C-B. Predictive validity of the Braden Scale for pressure ulcer risk in hospitalized patients. J Tissue Viability 2015 Aug;24(3):102-13. https://doi.org/10.1016/j. jtv.2015.05.001

22 Swafford K, Culpepper R, Dunn C. Use of a comprehensive program to reduce the incidence of hospital-acquired pressure ulcers in an intensive care unit. Am J Crit Care 2016 Mar;25(2):152-5. https://doi.org/10.4037/ajcc2016963

23 Boyko TV, Longaker MT, Yang GP. Review of the current management of pressure ulcers. Adv Wound Care 2018 Feb;7(2):57-67. https://doi.org/10.1089/wound.2016.0697

24 Lionelli GT, Lawrence WT. Wound dressings. Surg Clin North Am 2003 Jun;83(3):617-38. https://doi.org/10.1016/S00396109(02)00192-5

25 Furuya-Kanamori L, Walker RM, Gillespie BM, Clark J, Doi SAR, Thalib L. Effectiveness of different topical treatments in the healing of pressure injuries: a network meta-analysis. J Am Med Dir Assoc 2019 Apr;20(4):399-407. https://doi. org/10.1016/j.jamda.2018.10.010 